of any of the fossils, but it shows how expert opinion has differed regarding the interpretation of the relationships of the relatively fow specimens which have been found. The interpretation of fragmentary fossils is a ticklish business (witness the controversy regarding the significance of the Caithness fossil Palceospondylus, notwithstanding that scores of complete specimens are known), so that no one need be unduly disturbed by different interpretations of anthropoid fragments. Nevertheless, Mr. Dewar correctly sums up the position when he states that "science can truthfully say that it knows not when, where or how, man originated"; but he understates the truth when he says that this is all that science knows, for although there is "no conclusive evidence that any Primate genus has been transformed into any other genus", there are resemblances in detail and gradings which require much explana. tion if transformism is to be rejected. To say that "each new type appears in the rocks having all its characteristics, as if it had migrated from some other locality", simply pushes the problem back to the 'other locality'. How did it originate there?

\section{Special Creation or Evolution?}

Mr. Dewar does not say so, but probably he would agree with the view of the president of the Victoria Institute, Sir Ambrose Fleming, that man and every other genus began as a special creation. In support of that thesis, Sir Ambrose regards the Java, Heidelberg, Piltdown and Pekin 'men', as biological abnormalities, passing over the probabilities against the disappearance of all the normal forms of their time, and the preservation of abnormalities only. He holds that "if nearly as many [human] individuals die as are born in a year, there can be no particular contest for food and one of the factors in the Darwinian causes of evolution is thereby removed" ("Modern Anthropology versus Biblical Statements on Human Origin". Second edition. London: Victoria Institute, 1935. 1s.) But this mortality rate is what actually happens in every stable species of plant and animal, and the enormous destruction has generally been regarded as affording just that opportunity for selection which Darwin postulated. These and other aspects of the antiDarwin controversy are dealt with in a lively booklet by Sir Arthur Keith, "Darwinism and its Critics" (The Forum Series, No. 20. Pp. vii +56. London : Watts and Co., 1935. Paper, 7d. net; cloth, 1s. net), in which he defends the theory of evolution against the arguments of Sir Ambrose Fleming, and of other critics, some obviously ill-informed as to the facts. Sir Arthur clings to his hard-hitting style, but his punches are clean, and he swings a good knock-out. Also he adheres to the adage of a recent school grammar book-"explain clearly, as if to a Scotsman ..."

\section{London Television Station}

THE Postmaster-General announces that the Television Advisory Committee has recommended the adoption of the Alexandra Palace for the London
Television Station. This recommendation has been approved by the Postmaster-General; and the British Broadcasting Corporation has made arrangements with the Alexandra Palace trustees for the use of a portion of the buildings for the station. The ground at the Alexandra Palace is $306 \mathrm{ft}$. above sealevel ; and it is proposed to erect a $300 \mathrm{ft}$. mast on the site, thus providing an aerial height of $606 \mathrm{ft}$. above sea-level which, it is considered, should enable a high definition television service to be provided for the London area. The Baird Television Company and the Marconi-E.M.I. Television Company are being invited to tender for the supply of the necessary apparatus for the operation of their respective systems at the station. The Baird Company proposes the adoption of a standard of picture definition of 240 lines sequential scanning, 25 picture traversals a second, 25 complete frames a second; and the Marconi-E.M.I. Company propose a standard of 405 lines, 25 pictures a second, interlaced to give 50 frames a second, each of $202 \frac{1}{2}$ lines. The Committee proposes that the vision signals shall be radiated on a wave-length of about $6 \cdot 6$ metres and the associated sound signals on a wave-length of about $7 \cdot 2$ metres.

\section{Television in Germany}

A REgULAR television transmission service has already been inaugurated in Berlin by the German Post Office authorities, and arrangements are made whereby the public can attend demonstrations so that they may see for themselves what the new service has to offer. An article describing the proposals for the further development of television in Germany was given in the Wireless World of May 24, as an abstract of a paper by W. Scholz, recently published in Elektrische Nachrichten Technik. The television transmissions are of the 180 line, 25 pictures per second type and are given on ultra-short waves of less than 8 metres. Both sound and vision transmissions take place on these wave-lengths, so that a single heterodyne oscillator may be used at the receiver for both portions of the programme. A total band-width of 2,400 kilocycles per second is allocated to each station for the combined programmes. In the scheme proposed, it is assumed that a minimum field-strength of 1 millivolt per metre has to be provided, and that the transmitters will have aerial powers of from 2 to 20 kilowatts on wave-lengths between $5 \cdot 7$ and $7 \cdot 5$ metres. The lower-power stations will be erected on mountain peaks at heights ranging up to $4,000 \mathrm{ft}$., and it is estimated that the effective range of these stations will be of the order of 85 miles. On this basis, it is considered that the whole of Germany can be provided with a television service by means of twenty to thirty stations, the wave-lengths being distributed geographically so as to avoid mutual interference.

\section{Progress in the Gas Industry}

THE seventy-second annual general meeting of the Institution of Gas Engineers was held in London on June 4-7 under the presidency of Mr. C. Valon Bennett of Rochester. He reviewed the present 
position and general trends in the industry as a supplier of solid, liquid and gaseous fuels. There is a movement for gas works to pass into the control of holding companies, a process which has led at times to increased efficiency and a reduction in prices to the consumer. Mr. Bennett indicated the dangers to be feared where undertakings were bought at inflated prices, owing to the availability of cheap money, and where the motive force was financial opportunism irrespective of public good. In some countries, organisations have been established for the official testing and certification of gas appliances. Mr. S. Lacey and Mr. C. A. Masterman contended that such a movement could bring no advantage in Great Britain, where the safety and efficiency of gas apparatus already exceeds that current in other countries. Mr. W. L. Boon described the rapid advance of gas coke in public favour for domestic purposes. The development of the gravity feed boiler has resulted in coke displacing oil firing of central heating installations. With these boilers, uniform conditions can be maintained automatically, with attendance once in 24 hours, at a very low fuel cost. Open coke grates are increasing in popularity and already some 70,000 have been installed in London alone.

\section{Flock of Birds Mistaken for Sea-Serpent}

Lieut. A. J. Coвham, R.N., sends us an account of a flock of low-flying birds being mistaken for a sea-serpent. Similar observations have been made before, but it is worth while to put Lieut. Cobham's notes on record. On March 14, 1935, H.M.S. Electra was 100 miles S.W. of C. Spartel (North Africa). At about 17.30 G.M.T., weather being fine and visibility a maximum, Lieut. Cobham was on the bridge with a midshipman and a signalman. Suddenly to the westward, about 200 yards off, what seemed to be a sea-serpent was seen, travelling at about 30 knots on a slightly divergent course. "It had a small head, on the surface, ereating a bow-wave, and behind, at intervals of approximately 12 feet, there were four humps, each with a bow-wave. Every 20 seconds or so the beast submerged for a few moments. Inspection with binoculars showed the phenomenon to be a flock of small birds of the guillemot family (Alle alle or Fratercula arctica). They were flying in five ' $V$ '-formations, skimming so closely over the water that from time to time they were hidden by a swell. The light, due to a heat haze, was peculiar. The sea, to the westward, appeared to be an oily grey colour, against which the birds showed black. All three of us had the same impression on sighting, and so 'real' was the appearance that after establishing the truth with binoculars, the birds still looked exactly like a sea-serpent when seen with the naked eye."

\section{Avon Biological Research}

THE annual report of the biological research which is being carried out on the River Avon at Southampton in association with the University College there gives an account of the varied lines of work pursued in the second year of this scheme (Southampton : University College. 2s. 6d.). The general condition of the coarse fish in the area is described, with a special note on the incidence of 'black spot' disease among them. Methods are being sought for checking the loss of fish in mill-races, in the flooding of water-meadows, and by poisoning from decaying masses of weed. The use of green light has been tried to deter fish from entering dangerous waters, as well as a revolving fish screen which automatically keeps itself free from debris. Preliminary experiments have been made on the hatching and rearing of salmon and trout under natural and artificial conditions, and the resulting yield and condition of young fish were determined. The work was seriously hampered throughout by the drought conditions of 1933-34.

\section{National Institute of Agricultural Botany}

Tax fifteenth annual report (1933-34) of the National Institute of Agricultural Botany, Cambridge, shows that continued progress has been made in all departments. An important change in the stations at which crop testing is carried out took place in the autumn of 1934, when a new centre was established at Askham Bryan near York, in place of that at Good Easter, Essex, which was closed down. The results at the latter station had proved so similar to those at Cambridge, that it seemed more valuable to extend the Institute's activities in a northward direction. Two new winter wheats from the Cambridge University Plant Breeding Institute were tested $(162 / 8 / 1 E$, and $\mathrm{W} .70 A)$ and gave very promising results, while 'Resistance', the new winter oat which had proved so outstanding in former trials, was put on the market for distribution. Continued progress is recorded in the work of the Official Seed Testing Station, 29,487 samples being dealt with during the year under review. With regard to the activities of the Potato Testing Station at Ormskirk, eighty-seven entries were received for the official immunity trials, and all but three of these remained free from wart disease in the field. It is noteworthy that, with the exception of three varieties known to be duplicated, all the new varieties entered for the trials proved to be distinct. This is a striking tribute to the way in which the Potato Synonym Committee has been able to check the practice of distributing old varieties under new names and at an enhanced price.

\section{Report of the Development Commissioners}

THE twenty-fourth report $(1933-34)$ of the Development Commissioners which has just been published (London : H.M. Stationery Office. $2 s$. net) deals mainly with the various purposes for which advances from the fund were made to assist agriculture, rural economy and fisheries. In general, the allocation of grants was very similar to that in the previous year, but although no actual payments were made, arrangements were completed whereby the work at certain British institutes, hitherto financed by the Empire Marketing Board, could be continued. 